\title{
Management of Giant Retroperitoneal Liposarcoma: A Case Report
}

\section{Dev Retroperitoneal Liposarkomun Yönetimi: Bir Olgu Sunumu}

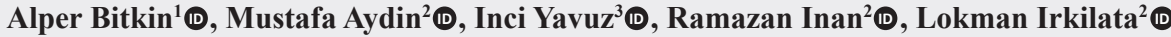 \\ ${ }^{1}$ Department of Urology, University of Health Sciences, Van Training and Research Hospital, Van, Turkey \\ ${ }^{2}$ Department of Urology, University of Health Sciences, Samsun Training and Research Hospital, Samsun, Turkey \\ ${ }^{3}$ Depatment of Pathology, University of Health Sciences, Samsun Training and Research Hospital, Samsun, Turkey
}

Cite as: Bitkin A, Aydin M, Yavuz I, Inan R, Irkilata L. Management of giant retroperitoneal liposarcoma: a case report. Grand J Urol 2021;1(1):33-6.

Submission date: 21 November 2020

Acceptance date: 23 November 2020

Online first: 06 January 2021

Publication date: 20 January 2021

Corresponding Author: Alper Bitkin / University of Health Sciences, Van Training and Research Hospital, Department of Urology, Van, Turkey alperbitkin@gmail.com ORCID: 0000-0003-4724-3053

\begin{abstract}
Retroperitoneal liposarcoma (RPLS) is a rare tumor. Early diagnosis and treatment are difficult due to absence of specific clinical presentations. We report a case of a 66-years-old woman who succesfully underwent complete surgical resection for a giant retroperitoneal liposarcoma. The complete surgical resection is the most important predictor of local recurrence and overall survival. We believe that complete surgical resection involving adjacent organs is a curative treatment to increase overall survival, especially in the presence of invasion of large tumors.
\end{abstract}

Keywords: retroperitonel, liposarcoma, large tumor, surgery

Öz

Retroperitoneal liposarkom (RPLS) nadir görülen bir tümördür. Belirgin klinik bulguların olmaması nedeniyle erken tanı ve tedavi zordur. Biz 66 yaşında kadın hastada dev bir retroperitoneal liposarkomun başarılı bir şekilde tam cerrahi rezeksiyon olgusunu sunuyoruz. Tam cerrahi rezeksiyon, lokal nüksün ve genel sağkalımın en önemli prediktörüdür. Komşu organları içeren tam cerrahi rezeksiyonun, özellikle büyük tümörlerin invazyonu varlığında genel sağ kalımı artırmak için önemli bir tedavi olduğuna inanıyoruz.

Anahtar Kelimeler: retroperitoneal, liposarkom, büyük tümör, cerrahi 


\section{Inroduction}

Retroperitoneal sarcomas represent $10-15 \%$ of all soft tissue sarcomas. The most common histological type of sarcomas is liposarcoma, accounting for $20-45 \%$ of cases [1]. Retroperitoneal liposarcoma (RPLS) usually occurs in 40-60 year-old patients, with a male /female ratio of 1:1 [2]. Because of the largeness of retroperitoneal area, liposarcomas are usually asymptomatic. When initially diagnosed, the sarcoma has reached a large size and often invades adjacent organs [3]. If needed a negative surgical margin should be provided by resection of adjacent organs to improve survival. However, the 5-year survival rate is $20 \%$ in the well-differentiated and $83 \%$ in the undifferentiated subtypes [4]. We report the management of a rare case of a giant $25 \mathrm{~cm}$ retroperitoneal liposarcoma.

\section{Case Presentation}

A 66-year-old female was admitted to our clinic with abdominal pain. On physical examination a hard, non-mobile mass extending from the bottom of the left costal margin towards the inguinal region was palpated. Contrast-enhanced abdominal computed tomography (CT) was performed. A $25 \times 16$ $\mathrm{cm}$ sarcoma mass surrounding the left kidney was detected on $\mathrm{CT}$, and the operation was planned (Figure 1). The patient was operated through a left semi-chevron incision. It was observed that the left kidney was completely surrounded by the mass. The mass and the left kidney were removed together (Figure 2). The operation time was $170 \mathrm{~min}$ and the estimated blood loss was $250 \mathrm{ml}$. No perioperative complication occured. The patient was discharged on the 4th postoperative day. The histopathologocical evaluation revealed a well-differentiated liposarcoma with a size of $25 \times 16 \times 12 \mathrm{~cm}$ (Figure 3). Neoadjuvant and/or adjuvant radiotherapy and chemotherapy were not given

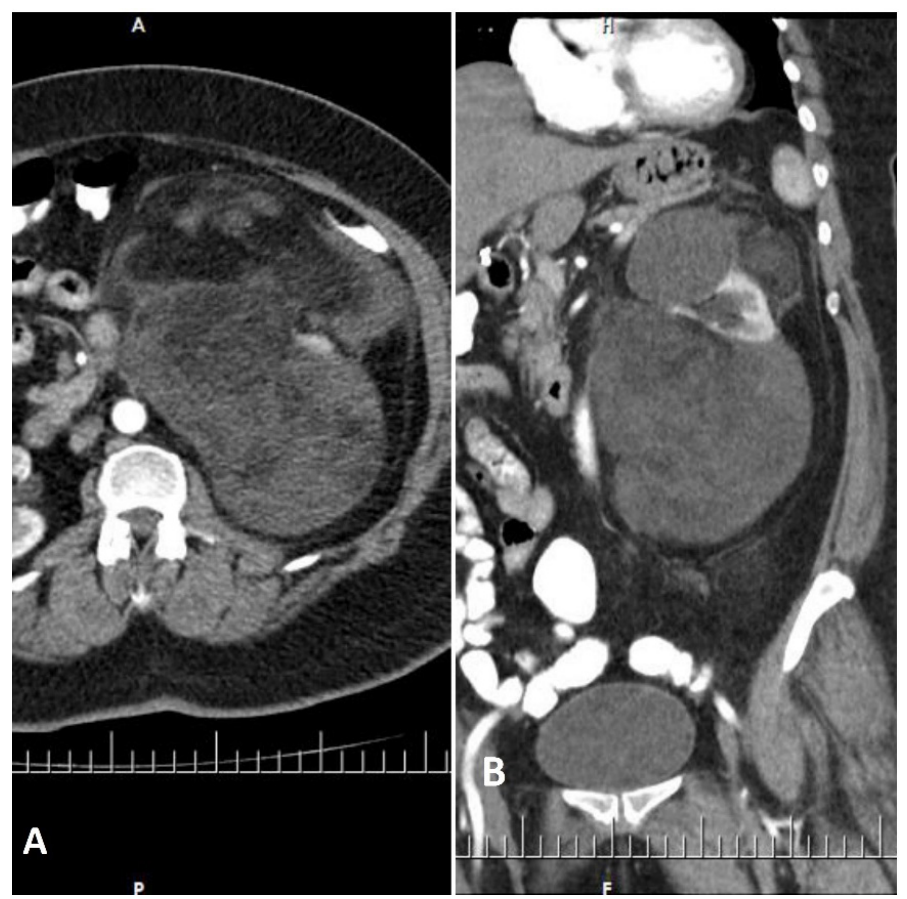

Figure 1. A- Contrast-enhanced abdominal computed tomography (CT) in the axial plane showing a large tumor in the abdomen B-Contrast enhanced CT scan in the coronal plane showing large tumor surrounding the left kidney to the patient. No recurrence or distant metastasis was detected in the postoperative 12 months of follow-up.

\section{Discussion}

RPLS is a rare tumor accounting for less than $0.2 \%$ of all malignancies. However, it is the most common type of retroperitoneal tumor. RPLS does not manifest typical symptoms, so it is difficult to make a diagnosis at an early stage. When clinical symptoms occur, the liposarcoma usually becomes large in size and compresses the adjacent organs [5]. Liposarcomas can be of different sizes and weights. Retroperitoneal liposarcomas

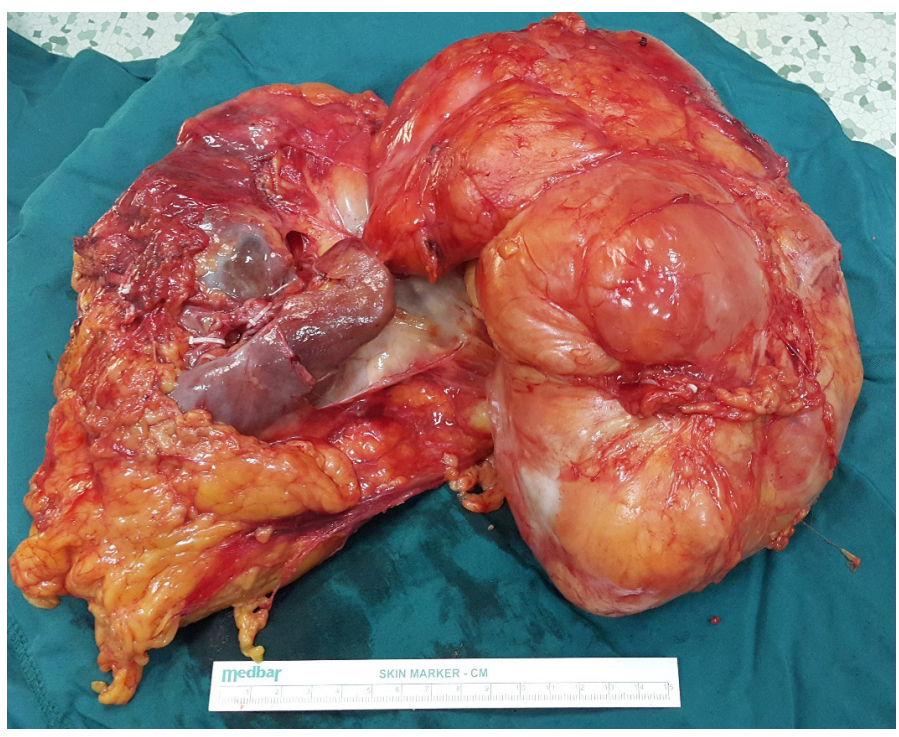

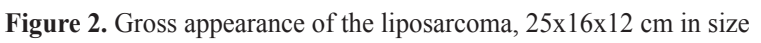

that weigh more than $20 \mathrm{~kg}$ are called giant liposarcomas and are extremely rare [2].

The most common diagnostic method for RPLS is CT. On CT imaging, liposarcomas appear as a large encapsulated mass containing different amounts of fat and soft tissue components. $\mathrm{CT}$ also helps in detecting tumor size, adjacent organ invasion, and distant metastases [6]. In our case, we used contrastenhanced abdominal $\mathrm{CT}$ as a diagnostic test.

The definitive diagnosis of RPLS is established by histopathological examination. RPLS histologically (undifferentiated, pleomorphic, well- differentiated, myxoid/ round cell RPLS) is divided into 4 groups [7]. Undifferentiated, pleomorphic types are high-grade carcinomas, and the rate of metastasis and recurrence is high. On the other hand, well -differentiated and myxoid / round cell types are low- grade carcinomas with a good prognosis [4]. Gronchi et al. reported overall 5-year survival rates for well-differentiated, myxoid/ round cell, undifferentiated and pleomorphic, as 90\%, $60-90 \%$, $75 \%$ and $30-50 \%$, respectively [8].

Complete surgical resection is the most important point of treatment. Successful complete resection of retroperitoneal liposarcoma has been shown to increase the 5 -year survival rate from $16.7 \%$ to $58 \%$ [9]. It has been shown that approximately $80 \%$ of RPLS patients are eligible for complete surgical 

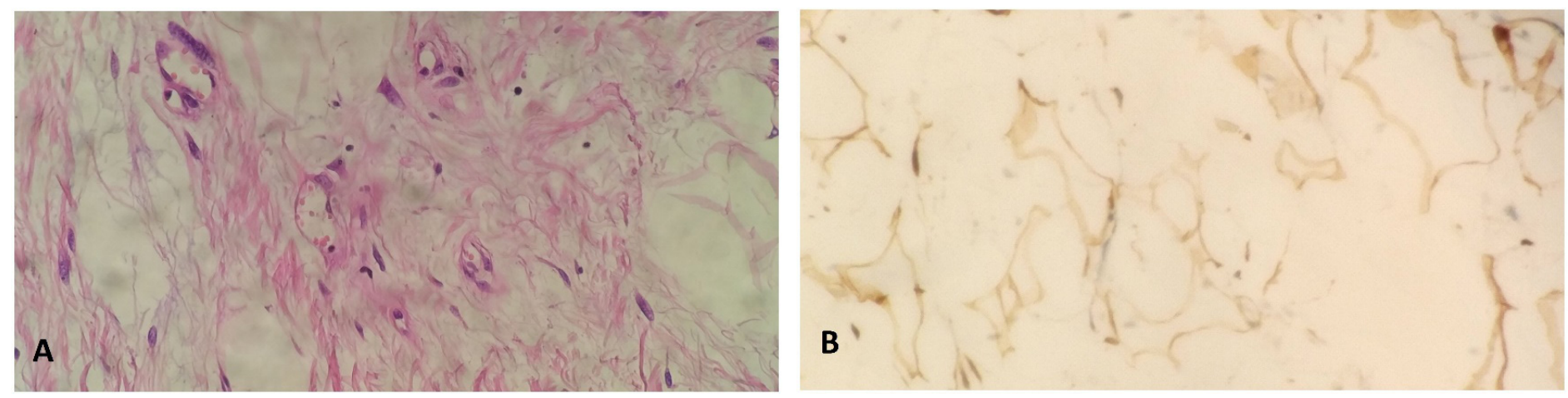

Figure 3. Histopathologic findings A- Well- differentiated liposarcoma (original magnification X100, H\&E staining) B- Atypical lipocytes with strong s-100 positivity are observed

resection and that this treatment prolongs the median survival time by 83 months and these patients have a 5 -year disease-free survival rate of $60 \%$. In another study, 3 and 5-year survival rates of patients who underwent complete resection were reported as $73 \%$ and $60 \%$, respectively [10]. Long-term prognosis is poor in patients without complete resection and 5-, and 10-year survival rates are $16.7 \%$ and $8 \%$, respectively [11].

To achieve complete removal of the tumor, $57.0-83.0 \%$ of patients with RPLS require resection of adjacent organs such as kidney, adrenal gland, ureter, colon, small intestine, omentum and spleen [10]. In addition, complete resection involving resection of organs adjacent to the tumor has been shown to be useful for the prevention of local recurrence. In RPLS cases, the most common resected organ during complete resection is the kidney [12]. Radical nephrectomy performed in cases of RPLS located near the kidney has a beneficial effect on disease-free survival [13]. In our case, a giant $25 \mathrm{~cm}$ liposarcoma located in the left retroperitoneal region was found to surround the left kidney. The mass and the kidney were removed all together to increase survival rates and achieve a negative surgical margin. Indeed, in our case surgical margin negativity was obtained. No local recurrence or distant metastasis was detected in CT at postoperative 3 th, 6 th, and 12 th months.

The benefits of using adjuvant chemotherapy and radiotherapy to improve survival in RPLS patients are controversial [10]. Adjuvant chemotherapy has been shown to benefit very few patients in a limited number of studies [13,14]. However, chemotherapy has been suggested, but it has worsened patient's prognosis [10]. The effectiveness of postoperative radiotherapy has been inquired in local control rather than overall survival [11]. Ballo et al. also stated that radiotherapy was ineffective in RPLS cases and radiotherapy applied may cause neuropathy, hydronephrosis, fistula and ileus [15]. It should not be ignored that radiotherapy to be applied to the retroperitoneal area may damage the visceral organs such as kidney, liver and intestines [15]. In our case of RPLS, we performed complete resection. Adjuvant radiotherapy and chemotreapy were not performed because the surgical margin was negative and histological subtype was well-differentiated liposarcoma.

In conclusion, RPLS is a rare tumor with a high rate of relapse without any typical symptoms. The large size of the mass at the time of diagnosis can make surgery difficult. Complete resection of the mass (resection of adjacent organs may also be required) is the most important step for treatment. In addition, histopathologic subtypes are important in survival. RPLS should be treated with a multidisciplinary approach and a long-term follow-up examination should be performed.

Ethics Committee Approval: N / A.

Informed Consent: An informed consent was obtained from the patient.

Publication: The results of the study were not published elsewhere in full or in part in the form of abstract.

Peer-review: Externally peer-reviewed.

Authorship Contributions: Any contribution was not made by any individual not listed as an author. Concept - A.B., M.A., L.I.; Design - A.B., I.Y., R.I., L.I.; Supervision - A.B., L.I.; Resources - A.B., I.Y.; Materials - A.B., M.A., I.Y.; Data Collection and/or Processing - A.B., M.A., I.Y., R.I.; Analysis and/or Interpretation - A.B., M.A., I.Y., R.I.; Literature Search A.B., M.A., I.Y., R.I.; Writing-A.B., M.A., I.Y.; Critical Review - A.B., MA., L.I.

Conflict of Interest: The authors declare that they have no conflict of interest.

Financial Disclosure: The authors have declared that they did not receive any financial support for the realization of this study.

\section{References}

[1] Lewis JJ, Leung D, Woodruff JM, Brennan MF. Retroperitoneal soft-tissue sarcoma: Analysis of 500 patients treated and followed at a single institution. Ann Surg 1998;228:355-65.

https://doi.org/10.1097/00000658-199809000-00008.

[2] Hashimoto Y, Hatakeyama S, Tachiwada T, Yoneyama T, Koie T, Kamimura N, et al. Surgical treatment of a giant liposarcoma in a Japanese man. Adv Urol 2010;2010:943073.

https://doi.org/10.1155/2010/943073.

[3] Dalal KM, Antonescu CR, Singer S. Diagnosis and management of lipomatous tumors. J Surg Oncol 2008;97:298-313. https://doi.org/10.1002/jso.20975. 
[4] Fabre-Guillevin E, Coindre JM, De Saint Aubain Somerhausen N, Bonichon F, Stoeckle E, Bui NB. Retroperitoneal liposarcomas: Follow-up analysis of dedifferentiation after clinicopathologic reexamination of 86 liposarcomas and malignant fibrous histiocytomas. Cancer 2006;106:2725-33. https://doi.org/10.1002/cncr.21933.

[5] Windham TC, Pisters PWT. Retroperitoneal sarcomas. Cancer Control 2005;12:36-43. https://doi.org/10.1177/107327480501200105.

[6] Chang IYJ, Herts BR. Retroperitoneal liposarcoma. J Urol 2013;189:1093-4. https://doi.org/10.1016/j.juro.2012.11.122.

[7] Crago AM, Singer S. Clinical and molecular approaches to well differentiated and dedifferentiated liposarcoma. Curr Opin Oncol 2011;23:373-8. https://doi.org/10.1097/CCO.0b013e32834796e6.

[8] Gronchi A, Collini P, Miceli R, Valeri B, Renne SL, Dagrada $\mathrm{G}$, et al. Myogenic differentiation and histologic grading are major prognostic determinants in retroperitoneal liposarcoma. Am J Surg Pathol 2015;39:383-93. https://doi.org/10.1097/PAS.0000000000000366.

[9] Lee SY, Goh BKP, Teo MCC, Chew MH, Chow PKH, Wong WK, et al. Retroperitoneal liposarcomas: The experience of a tertiary Asian center. World J Surg Oncol 2011;9:12. https://doi.org/10.1186/1477-7819-9-12.

[10] Wu YX, Liu JY, Liu JJ, Yan P, Tang B, Cui YH, et al. A retrospective, single-center cohort study on 65 patients with primary retroperitoneal liposarcoma. Oncol Lett 2018;15:1799-810. https://doi.org/10.3892/ol.2017.7533.
[11] Zeng X, Liu W, Wu X, Gao J, Zhang P, Shuai X, et al. Clinicopathological characteristics and experience in the treatment of giant retroperitoneal liposarcoma: A case report and review of the literature. Cancer Biol Ther 2017; 18:660-5. https://doi.org/10.1080/15384047.2017.1345388.

[12] Singer S, Antonescu CR, Riedel E, Brennan MF, Pollock RE. Histologic Subtype and Margin of Resection Predict Pattern of Recurrence and Survival for Retroperitoneal Liposarcoma. Ann Surg 2003;238:358-71. https://doi.org/10.1097/01.sla.0000086542.11899.38.

[13] Rhu J, Cho CW, Lee KW, Park H, Park JB, Choi Y La, et al. Radical Nephrectomy for Primary Retroperitoneal Liposarcoma Near the Kidney has a Beneficial Effect on Disease-Free Survival. World J Surg 2018;42:254-62. https://doi.org/10.1007/s00268-017-4157-6.

[14] Pervaiz N, Colterjohn N, Farrokhyar F, Tozer R, Figueredo A, Ghert M. A systematic meta-analysis of randomized controlled trials of adjuvant chemotherapy for localized resectable soft-tissue sarcoma. Cancer 2008;113:573-81. https://doi.org/10.1002/cncr.23592.

[15] Ballo MT, Zagars GK, Pollock RE, Benjamin RS, Feig BW, Cormier JN, et al. Retroperitoneal soft tissue sarcoma: An analysis of radiation and surgical treatment. Int $\mathrm{J}$ Radiat Oncol Biol Phys 2007;67:158-63. https://doi.org/10.1016/j.ijrobp.2006.08.025. 